${ }^{1}$ PORÁČOVÁ, J., 'ZAHATŇANSKÁ, M., ${ }^{2}$ NAGY, M., ${ }^{1}$ KONEČNÁ, M., ${ }^{1}$ MYDLÁROVÁ BLAŠČÁKOVÁ, M., ${ }^{1}$ SEDLÁK, V., ${ }^{3}$ TKÁČOVÁ, R. ${ }^{1}$

\title{
TERTIARY EDUCATION IN EU COUNTRIES
}

Increasing the number of people who complete tertiary (higher) education and improving its quality are important for sustainable and inclusive growth. Higher rates of tertiary education attainment, combined with better quality and relevance, can attenuate skills shortages in knowledge-intensive economic sectors. This in turn promotes productivity growth, innovation and competitiveness. Given the fast pace of technological progress and the intensity of global competition, with labour markets requiring ever-increasing skill levels, high tertiary education attainment levels can sustain smart, sustainable growth. Education, together with health, is considered one of the most important priorities in which many countries invest the most money. Education has a significant potential to stimulate socio-economic development. In today's globalized world, there is a need for a highly-skilled workforce in terms of competitiveness, labour productivity and innovation trends (European Commission 2015).

Education, vocational training and lifelong learning play a key role in the European Union's (EU) economic and social strategies. Education and Training 2020 (ET 2020) provides a strategic framework for European cooperation in these areas of education. It pursues four common goals: to implement lifelong learning and mobility a reality; improve the quality and efficiency of education and training; to promote equality, social cohesion and active citizenship; increase creativity and innovation, including entrepreneurship. International standard classification of education (ISCED 2015; Rektořík et al. 2007).

As national education systems vary in terms of structure and curricular content, it can be difficult to make spatial or temporal comparisons when assessing their performance. In order to interpret the inputs, processes and outcomes of education systems, official statistics on education are compiled according to the International Standard Classification of Education (ISCED 2015). It is used to collect a variety of statistics covering topics such as enrollment and attendance, educational attainment or human or financial investment. Table 1. shows the EU regions with the highest proportion of people with a university degree.

The term tertiary education is used to refer to higher levels of education (ISCED levels 5-8). In 2018, there were almost 92 million children, pupils, and students enrolled across the EU in all levels of education from early childhood through to doctoral studies. Tertiary education (ISCED levels 5-8) builds on secondary education, providing learning activities at a higher level of complexity. It is offered by universities, vocational establishments, institutes of technology, as well as other institutions awarding academic degrees and/or professional certificates (OECD 2017; NESET 2013).

\footnotetext{
11 University of Prešov, Faculty of Humanities and Natural Sciences, 17th November Street, 08001 Prešov, Slovak Republic

2J. Selye University, Bratislavska cesta 3322, 94501 Komárno, Slovak Republic

${ }^{3}$ Technical University of Košice, Department of Social Sciences, Vysokoškolská 4, 04200 Košice, Slovak Republic
} 
Table 1. Percentage of people aged 30-34 years with the highest proportion of people with a university degree

\begin{tabular}{|l|l|l|l|}
\hline Order & Community/ Region & $\begin{array}{l}\text { Percentage } \\
\text { (\%) }\end{array}$ & Country \\
\hline & EU & $\mathbf{4 0 . 3}$ & European Union \\
\hline $\mathbf{1 .}$ & Sostinés regionas & 70.4 & Lithuania \\
\hline $\mathbf{2 .}$ & Warszawski stoleczny & 69.2 & Poland \\
\hline $\mathbf{3 .}$ & Hovedstaden & 64.2 & Denmark \\
\hline $\mathbf{4 .}$ & Utrecht & 64.1 & Netherlands \\
\hline $\mathbf{5 .}$ & Stockholm & 63.4 & Sweden \\
\hline $\mathbf{6 .}$ & lle-de-France & 63.2 & France \\
\hline $\mathbf{7 .}$ & Noord Holland & 62.1 & North Holland \\
\hline $\mathbf{8 .}$ & Bratislavský kraj & 62.1 & Slovak Republic \\
\hline $\mathbf{9 .}$ & Praha & 60.9 & Czech Republic \\
\hline $\mathbf{1 0 .}$ & Pais Vasco & 59.0 & Spain, Basque Country \\
\hline
\end{tabular}

(Source: Own processing according to Eurostat 2019 data)

Less than half of all EU regions have achieved the policy goal they have set for tertiary education.

Within the EU, information was collected on the proportion of the population aged 30-34 who successfully completed the tertiary education program. This age group was chosen because most students completed tertiary education during their twenties (even if they completed a master's or postgraduate course). This indicator is part of the scoreboard used to monitor the European Pillar of Social Rights and is also the ET 2020 reference indicator. The goal is to increase tertiary education attainment in the EU to at least $40 \%$ by 2020 . In 2019 , more than two-fifths (40.3\%) of the EU-27 population aged 30-34 had a tertiary education; the ET 2020 reference value has been reached. A more detailed regional analysis pointed to significant territorial differences - both within and between EU Member States. In 101 NUTS level 2 regions (out of 237 for which data are available), at least $40.0 \%$ of people aged 30-34 with tertiary education were in 2019. The highest number of university graduates was achieved in nine regions with a share of at least $60.0 \%$. These are the regions of the capital of the Czech Republic, Denmark, France, Lithuania, the Netherlands, Poland, Slovak Republic and Sweden. Utrecht also belongs to this group, where there is a research centre with one of the largest universities in the Netherlands. In most of the remaining multi-region of the EU Member States, the capital region recorded the highest share of tertiary education attained (European Commission 2019; Eurostat 2019).

The only exceptions where the highest share was recorded in the non-capital region were the provinces of Vlaams-Brabant (Belgium), País Vasco (Spain), Adriatic Croatia (Croatia), Emilia-Romagna (Italy) and Utrecht. The regions of the capital attract highly qualified people, offering them various opportunities for education, employment, social contacts, lifestyle. Data from 2019 show the share of people aged 30-34 with tertiary education, which remained below the ET 2020 reference value of $40.0 \%$ in more than half of the regions (Picture 1.).

Many of them are rural or sparsely populated regions with a relatively large agricultural sector with a low level of highly skilled employment. In the eastern parts of many countries (Germany, Italy, Portugal, and several eastern EU Member States), every region, except the capital region, has experienced a relatively low take-up of tertiary education; opportunities reflects a traditional practice of following vocational programs instead. 
Picture 1.: Tertiary educational attainment of people aged 30.34 years, 2019 (\%, by NUTS 2 regions

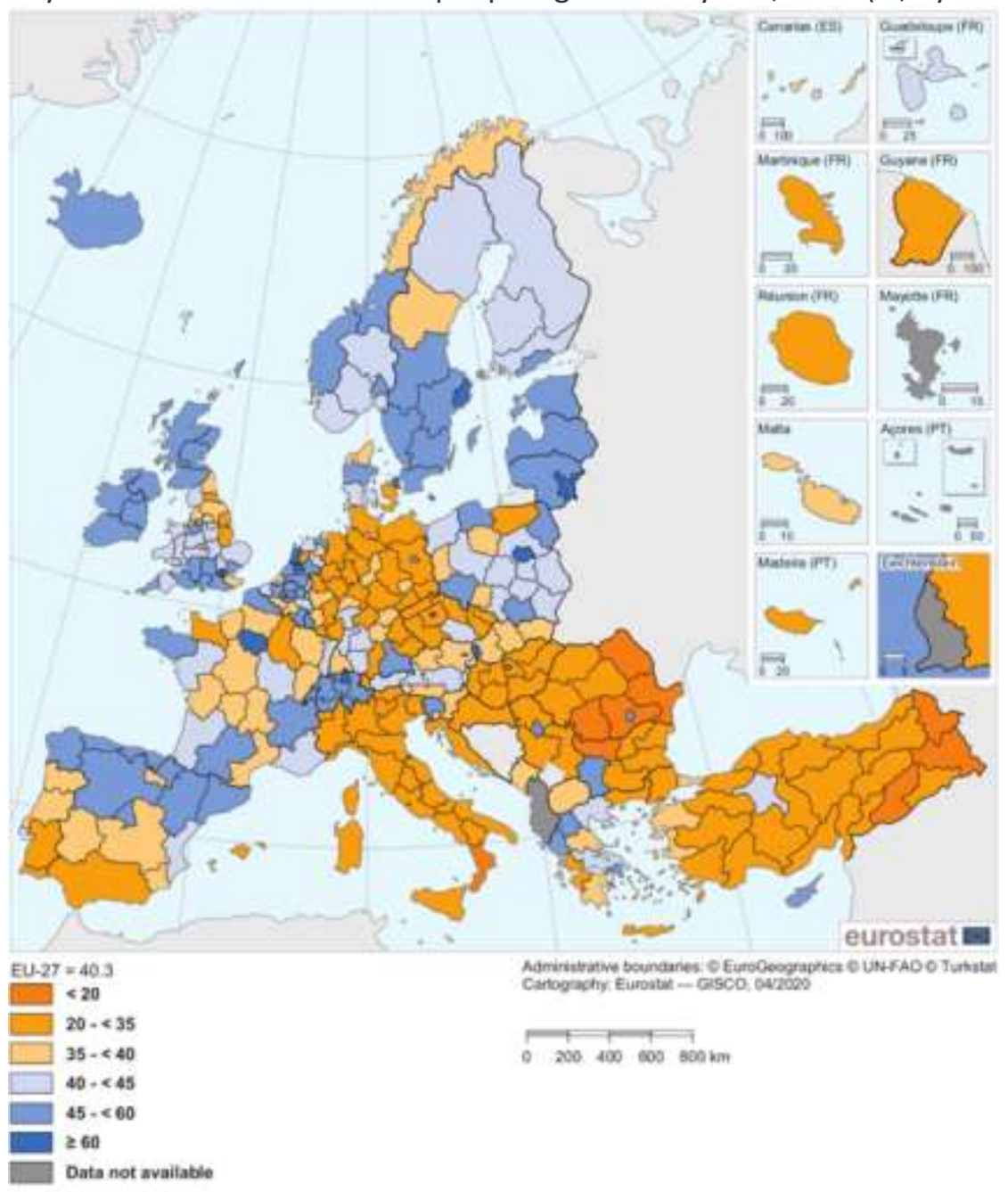

(Source: Eurostat, 2019)

\section{Application of tertiary education graduates in practice}

Many different terms have been used in the higher education literature to describe the generic skills of graduates, and these commonly include the following: graduate attributes, competencies, qualities or outcomes; generic attributes; transferable, employability or soft skills; and core capabilities (Hill et al. 2016). The hierarchy develops from graduate attributes as specific knowledge, skills and values, through graduate profiles that refer to the summation of attributes at either programme or institutional level, culminating in the term graduate outcome, which is used to encompass both graduate attributes and graduate profiles. Graduate attributes are broader and more encompassing than employability, helping to develop academic, citizenship and career competencies. After graduation, there may be certain obstacles that reduce graduates' ability to enter the labour market. This is, in particular, the lack of relevant work experience, lack of skills, new technologies and globalization affecting industries. The overall shortage of jobs (during the economic crisis) is also an obstacle.

Each of the EU Member States is responsible for its own education and training policy. However, the EU supports national actions and helps Member States to address common education and training challenges through what is known as the open method of coordination: indeed, the EU provides a policy forum for discussing topical issues (for example, ageing societies, the skills deficits, or global competition) and also allows Member States an opportunity to exchange best practices (European Commission 2019). 
The ET 2020 framework supports the EU Member States through policy cooperation and funding instruments: these include the Erasmus+ programme and European structural and investment funds. In 2015, there was a stocktaking exercise in relation to the implementation of the ET 2020, which resulted in six new priority areas for European cooperation, namely: promoting lifelong learning with a focus on learning outcomes for employability, innovation, active citizenship and well-being; inclusive education and the promotion of civic competences; open and innovative education and training; support for teachers, trainers, school leaders and other educational staff; transparency and recognition of skills and qualifications to facilitate learning and labour mobility; sustainable investment, quality and efficiency of education and training systems. The EU is in the process of building a European learning area aimed at enhancing learning outcomes and learning mobility, promoting common values and facilitating the mutual recognition of diplomas across borders. Since 2018, the European Commission has presented a number of initiatives aimed at improving the development of key competences (such as literacy, languages, digital skills and entrepreneurship); to make better use of digital technologies for teaching and learning, and to develop mutual recognition of diplomas (European Commission 2014).

In his policy guidelines, the President of the European Commission pointed to the need to create a European learning area by 2025. In this learning area, it is important to remove barriers to learning; improving access to education; to enable students to move more freely between education systems in different countries; enriching life chances by promoting lifelong learning; and promoting investment in digital skills for both young people and adults (European Commission 2020; OECD 2017).

In the EU-28, there were 19.8 million tertiary education students in 2017 , of which $61 \%$ were studying for bachelor's degrees. In 2017, women accounted for $54 \%$ of all tertiary students in the EU-28; however, a majority of the students following doctoral studies were men. In 2017, nearly one-quarter of tertiary education students in the EU-28 were studying business, administration or law (Eurostat 2017).

Tertiary education, which is provided by universities and other higher education institutions, is very important in society, encourages innovation, increases economic development and growth, and significantly improves the living standards of citizens. Some European universities are among the most prestigious in the world. In the coming period, the demand for highly qualified workers will increase. Qualifications already exist in some EU Member States (OECD 2014).

Thanks to digital technologies, the supply of jobs is more flexible, but also more difficult for education and subsequently for work performance. The development of digital technologies has resulted in a growing number of employers looking for employees with the necessary capacity to manage complex information, creativity, independent thinking, intelligent and efficient use of resources and effective communication. In the present time, a relatively large number of students in tertiary education are internationally mobile and study abroad (Mager and Spronken-Smith 2014).

In 2017, there were 19.8 million tertiary students in the EU-28 (Table 2.), of which 7.4\% studied in short-cycle tertiary courses, $61.0 \%$ in bachelor's studies, $27.7 \%$ in master's studies and $3,8 \%$ for doctoral degree degrees. In 2017, Germany, the most populous EU Member State, had 3.1 million tertiary students, the highest number in the EU, accounting for $15.6 \%$ of the total EU-28. The next largest populations of tertiary students were France (12.8\% of the total), the United Kingdom (12.3\%), Spain (10.2\%), Italy (9.3\%) and Poland (7.8\%), followed by the Netherlands, where $4.4 \%$ studied EU-28 tertiary students (OECD 2017, Eurostat 2017). 
Table 2.: Tertiary education in the countries of EU - Bachelor and Master degree of female and male

\begin{tabular}{|c|c|c|c|c|c|c|c|c|c|}
\hline \multirow[t]{2}{*}{ Country } & \multicolumn{3}{|c|}{ Tertiary total } & \multicolumn{3}{|c|}{ Bachelor's } & \multicolumn{3}{|c|}{ Master's } \\
\hline & Total & Male & Female & Total & Male & Female & Total & Male & Female \\
\hline Belgium & 526.8 & 233.7 & 293.0 & 384.2 & 169.0 & 215.2 & 102.1 & 46.8 & 55.3 \\
\hline Bulgaria & 249.9 & 115.6 & 134.3 & 165.6 & 79.5 & 85.1 & 77.6 & 32.9 & 44.7 \\
\hline Czech Rep. & 352.9 & 150.4 & 202.5 & 206.1 & 88.2 & 117.9 & 122.3 & 48.8 & 73.5 \\
\hline Denmark & 312.4 & 136.1 & 176.3 & 196.0 & 81.2 & 114.8 & 71.2 & 31.4 & 39.8 \\
\hline Germany & $3,091.7$ & $1,592.0$ & $1,499.7$ & $1,859.8$ & 997.2 & 862.6 & $1,033.3$ & 484.2 & 549.0 \\
\hline Estonia & 47.8 & 19.6 & 28.1 & 30.3 & 12.9 & 17.4 & 14.9 & 5.6 & 9.3 \\
\hline Ireland & 225.0 & 109.0 & 116.1 & 166.9 & 8.3 & 84.6 & 30.2 & 13.4 & 16.8 \\
\hline Greece & 735.0 & 378.1 & 357.0 & 634.0 & 333.8 & 302.2 & 72.3 & 29.2 & 43.1 \\
\hline Spain & $2,010.2$ & 938.4 & $1,071.8$ & $1,211.6$ & 555.2 & 656.4 & 334.5 & 141.9 & 192.6 \\
\hline France & $2,532.8$ & $1,153.5$ & $1,379.3$ & $1,041.8$ & 431.8 & 610.0 & 922.9 & 429.4 & 493.4 \\
\hline Croatia & 165.2 & 71.4 & 93.8 & 99.1 & 46.3 & 52.8 & 62.7 & 23.6 & 39.1 \\
\hline Italy & $1,837.1$ & 815.1 & $1,022.0$ & $1,102.1$ & 509.3 & 592.0 & 696.2 & 284.0 & 412.2 \\
\hline Latvia & 82.9 & 34.9 & 48.0 & 48.3 & 21.5 & 26.9 & 17.7 & 6.4 & 11.3 \\
\hline Lithuania & 125.9 & 54.7 & 71.2 & 95.5 & 43.4 & 52.1 & 27.6 & 10.1 & 17.5 \\
\hline Luxembourg & 7.1 & 3.5 & 3.6 & 3.2 & 1.6 & 1.6 & 2.5 & 1.2 & 1.3 \\
\hline Hungary & 287.0 & 131.3 & 155.7 & 187.3 & 88.8 & 98.6 & 79.0 & 33.0 & 45.1 \\
\hline Netherlands & 875.5 & 417.7 & 457.8 & 659.6 & 319.8 & 339.8 & 176.9 & 79.4 & 97.5 \\
\hline Austria & 430.4 & 202.9 & 227.5 & 196.0 & 92.0 & 103.1 & 135.6 & 62.2 & 73.3 \\
\hline Poland & $1,550.2$ & 634.8 & 915.4 & $1,027.2$ & 448.5 & 578.7 & 479.6 & 166.9 & 312.7 \\
\hline Portugal & 347.0 & 162.3 & 184.7 & 200.6 & 91.5 & 109.1 & 15.8 & 54.6 & 61.2 \\
\hline Romania & 531.6 & 245.0 & 286.6 & 347.9 & 168.5 & 179.4 & 164.5 & 66.6 & 98.0 \\
\hline Slovenia & 79.5 & 33.8 & 45.7 & 44.1 & 18.1 & 26.0 & 21.9 & 7.9 & 13.0 \\
\hline Slovakia & 156.0 & 63.6 & 92.5 & 85.3 & 35.5 & 49.8 & 60.5 & 23.1 & 37.4 \\
\hline Finland & 295.5 & 138.5 & 157.0 & 211.1 & 101.8 & 109.3 & 65.6 & 27.8 & 37.8 \\
\hline Sweden & 426.4 & 172.5 & 253.0 & 240.7 & 87.9 & 152.8 & 140.7 & 61.2 & 79.6 \\
\hline EU-28 & $19,773.2$ & $9,088.9$ & $10,684.4$ & $12,071.6$ & $5,628.6$ & $6,442.9$ & $5,484.8$ & $2,355.0$ & $3,129.8$ \\
\hline
\end{tabular}

(Source: Own processing according to Eurostat 2019 data)

In 2017, more students studied at the bachelor's degree level than at any other level of tertiary education in each of the EU Member States. France, Luxembourg, Austria and Cyprus were the only Member States where less than $50 \%$ of all tertiary students studied for bachelor's degrees. In the Netherlands (75.3\%) and Lithuania (75.9\%), more than three quarters of university students studied at the bachelor's level, and this share increased to almost nine-tenths in Greece (86.3\%). Less than one fifth of all tertiary students was studying for a master's degrees in 2017 in Belgium, the United Kingdom, Spain and Ireland (as well as Serbia among the candidate countries), with this share falling below one-tenth in Greece (as well as in Turkey, Montenegro and North Macedonia). More than onethird of tertiary students were studying for master's degrees in Portugal, Germany, Czech Republic, Luxembourg, France, Italy, Croatia, Slovak Republic and Cyprus (Eurostat 2017).

In 2017, women accounted for $54.0 \%$ of all tertiary students in the EU-28. The share of women among tertiary students was slightly higher among those studying for master's degrees (57.1\%), somewhat lower for those studying for bachelor's degrees (53.4\%). In 2017, close to three-fifths of all tertiary students in Sweden, Slovakia, Poland, and Estonia were women. Women were also in a majority among tertiary students in all other EU Member States except for Greece (where they accounted for $48.6 \%$ of tertiary students) and Germany (48.5\%). Across the EU-28, more than one fifth (22.2\%) of all students in tertiary education were studying business, administration or law in 2017. Women accounted for a majority of the total number of students within this field of education. The second most common field of education was engineering, manufacturing and construction-related studies, which accounted for 
15.3\% of all tertiary education students. In this field, almost three-quarters of all students were male. The third-largest field of study was health and welfare, with a $13.6 \%$ share of all tertiary education students (Eurostat 2017).

\section{Conclusion}

Tertiary education provided by universities and other higher education institutions play an essential role in society by fostering innovation, increasing economic development and growth, and improving more generally the well-being of citizens. Some European universities are among the most prestigious in the world. Many commentators predict that in the coming years, there will be increased demand for highly skilled people. Driven by digital technology, jobs are becoming more flexible and complex. This has resulted in a growing number of employers seeking staff with the necessary capacities to manage complex information, think autonomously, be creative, use resources in a smart and efficient manner, as well as communicate effectively. Education is an essential part of any modern, successful and rich country. EU countries are no exception. The need for a university-educated workforce is increasing every year by employers. Educated graduates and workers are also needed in other areas of society, e.g. in healthcare, in the economic, social, legal, education, etc. One of the EU's main challenges is to ensure that policy developments are monitored to take account of the considerable geographical diversity in the EU. The territorial dimension of EU policy is increasingly recognized, as growth and job creation depend on making the best use of all resources while ensuring the coordinated and sustainable use of shared resources. This section provides an overview of some of the main EU policy developments that have a territorial impact.

\section{References}

- EUROPEAN COMMISSION (2020): Higher Education policy. [Cited: 2020.10.11]. http://ec.europa.eu/education/policy/higher-education/

- EUROPEAN COMMISSION / EACEA / (2014): Eurydice: Modernisation of Higher Education in Europe: Access, Retention and Employability, Brussels. [Cited: 2020.10.11]. http://eacea.ec.europa.eu/education/eurydice/documents/thematic reports/165EN.pdf

- EUROSTAT (2015): Eurostat regional yearbook. Manual: Guidelines. [Cited: 2020.10.11]. https://ec.europa.eu/eurostat/statisticsexplained/index.php?title=Eurostat regional yearbook, https://ec.europa.eu/assets/eac/education/tools/docs/2015/monitor15-vol-2 en.pdf

- EUROSTAT (2017): Tertiary education statistics. Manual: Guidelines. [Cited: 2020.10.11]. https://ec.europa.eu/eurostat/statisticsexplained/index.php?title=Tertiary education statistics\#Fields of education

- EUROSTAT (2019): Education - and - training. Manual: Guidelines. [Cited: 2020.10.11]. https://ec.europa.eu/eurostat/web/education-and-training/publications

- Jennifer Hill, Helen Walkington, Derek France (2016): Graduate attributes: implications for higher education practice and policy. Journal of Geography in Higher Education. p. 155-163. [Cited: 2020.10.11]. DOI: https://doi.org/10.1080/03098265.2016.1154932

- Sarah Mager, Rachel Spronken-Smith (2014): Graduate attribute attainment in a multi-level undergraduate geography course. Journal of Geography in Higher Education, vol. 38, 238-250. [Cited: 2020.10.11]. DOI: 10.1080/03098265.2014.910757

- Jocey Quinn (2013): Drop-out and Completion in Higher Education in Europe among students from under-represented groups. NESET Report, [Cited: 2020.10.11]. http://www.nesetweb.eu/sites/default/files/HE\%20Drop\%20out\%20AR\%20F.inal.pdf

- OECD (2014): Education at a Glance 2014. OECD indicators, http://www.oecd.org/edu/Education-at-aGlance-2014.pdf OECD (2014b), Reviews of 
Evaluation and Assessment. Slovak Republic 2014, http://www.oecd.org/slovakia/oecdreviews-of-evaluation-and-assessment-in-education-slovak-republic2012-9789264117044en.htm

- OECD (2017): Education at a Glance 2017: OECD Indicators, OECD Publishing, Paris. http://dx.doi.org/10.1787/eag-2017-en; Portál U-Multirank. [Cited: 2020.10.11]. http://www.umultirank.org/\#!/home?name=null\&trackType=home

- OECD (2017): Education at a Glance 2017: OECD Indicators, OECD Publishing, Paris. http://dx.doi.org/10.1787/eag-2017-en; Portál U-Multirank. [Cited: 2020.10.11]. http://www.umultirank.org/\#!/home?name=null\&trackType=home

- OECD/Eurostat/UNESCO Institute for Statistics (2015): “ISCED 2011 Level 5: Short-cycle tertiary education", in ISCED 2011 Operational Manual: Guidelines for Classifying National Education Programmes and Related Qualifications, OECD Publishing, Paris. [Cited: 2020.10.11]. DOI: https://doi.org/10.1787/9789264228368-10-en

- Rektořík Jaroslav, kolektiv (2007): Ekonomika a řízení odvětví veřejného sektoru. 2. vyd. Praha: Ekopress, s.r.o., 312 s. ISBN 978-80-86929-29-3. 